\title{
Erratum to: Gene mapping in the wild with SNPs: guidelines and future directions
}

Jon Slate $\cdot$ Jake Gratten $\cdot$

Dario Beraldi · Jessica Stapley .

Matt Hale $\cdot$ Josephine M. Pemberton

Published online: 4 March 2010

(C) Springer Science+Business Media B.V. 2010

Erratum to: Genetica (2009) 136:97-107

DOI 10.1007/s10709-008-9317-z

This article was intended for publication in the Special Issue of Ecological Genomics.
An error of classification during peer review process has prevented its inclusion in this special issue, as it has been published earlier in Volume 136, Number 1.

The online version of the original article can be found under doi: 10.1007/s10709-008-9317-z.

J. Slate $(\bowtie) \cdot$ J. Gratten · J. Stapley $\cdot$ M. Hale

Department of Animal \& Plant Sciences, University of Sheffield,

Sheffield S10 2TN, UK

e-mail: j.slate@shef.ac.uk

D. Beraldi · J. M. Pemberton Institute of Evolutionary Biology, University of Edinburgh,

Edinburgh EH9 3JT, Scotland, UK

Present Address:

M. Hale

Department of Forestry and Natural Resources, Purdue

University, West Lafayette, Indiana 47907-1159, USA 